УДК [338.48:005]:001(477)

UDC [338.48:005]:001(477)

DOI: $10.31475 /$ ped.dys.2021.30.07

ОЛЕСЯ ДОЛИНСЬКА, доктор фбілософбї

(Україна, Хлельнищький, Хлельнищька гуланітарно-педагогічна акаделія, вул. Проскурівського підпілля, 139)

OLESIA DOLYNSKA,

Doctor of Philosophy

(Ukraine, Khmelnytskyi, Khmelnytskyi Humanitarian-Pedagogical Academy, Proskurivskoho

Pidpillia St., 139)

ORCID: 0000-0002-7977-5700

\title{
Особливості використання регіонального компоненту у підготовці студентів спеціальності 242 «Туризм»
}

\section{Features of Using the Regional Component in Training Students of Program Subject Area 242 «Tourism»}

\begin{abstract}
Розглянуто використання регіонального колпоненту у підготовиі студентів спеціальності 242 «Туризл». Унікальність освітньої програли полягає у розвитку туристичної діяльності в умовах розвитку територіальних громад Хмельниччини. Регіональний компонент представлений в дисциплінах. Розвиток регіонального туристичного колплексу відбувається під впливом взаємодї економічних, соціальних, природних, екологічних чинників. Регіональний туристичний колплекс Хмельницької області має у складі 58 точкових елелентів територіальної структури та 2 дисперсні туристичні кущі з вузлали в містах Кам'янецьПодільський $і$ Хлельницький. На території регіону фбункиіонує 18 моно- $i 17$ біфбункиіональних туристичних пунктів та 1 моно- $i 10$ біфункиіональних центрів, а також 1 моно- $i 2$ біфбункиіональні кластери. Вказано головні галузеві напряли перспективного розвитку туризлу, проблеми у розвитку туристичного колплексу Хлельниччини. Ці знання е важливили у підготовиі студентів спеціальності 242 «Туризм».
\end{abstract}

Ключові слова: підготовка студентів, туризл, Хлельницька область, туристична галузь.

The article considers the possibilities of using the regional component in the training of students of Program Subject Area 242 "Tourism". The uniqueness of the educational program lies in the development of tourism in the formation and development of territorial communities of Khmelnytsky region. Cooperation with regional enterprises has been established. Applicants are involved in the practical development and implementation of a tourist product within the project "Tourist Magnets". There is a scientific circle "Tourism Expert».The regional component is presented in disciplines. It is noted that the development of the regional tourist complex of Khmelnytsky region is influenced by the interaction of the following factors: economic, social, natural, environmental. Social infrastructure is important for the organization of full-fledged recreation of tourists: the availability of housing and communal services, cultural and household services, health care, trade. The current available nature reserve and historical and cultural funds of Khmelnytsky region are used very unevenly. The regional tourist complex of Khmelnytsky region consists of 58 point elements of the territorial structure and two dispersed tourist bushes with nodes in the cities of Kamyanets-Podilsky and Khmelnytsky. There are 18 mono- and 17 bifunctional tourist points and 1 mono- and 10 bifunctional centers, as well as 1 monoand 2 bifunctional clusters in the region. The main branch directions of perspective development of tourist activity of Khmelnytsky region which need to be realized through carrying out of changes in the territorial organization of a regional tourist complex are specified. Emphasis is placed on the main problems in the development of the tourist complex of Khmelnytsky region. This knowledge is important in the preparation of students of Program Subject Area 242 «Tourism».

Keywords: preparation of students, tourism, Khmelnytskyi region, tourist branch.

Вступ / Introduction. Туризм визначений як пріоритетна галузь розвитку економіки України та Хмельницької області. Історико-культурні надбання, географрічні та кліматичні умови забезпечують чудові умови для розвитку туризму на Хмельниччині. Туризм як прибуткова галузь економіки набувае особливого значення для розвитку Хмельниччини. В час пандемії в Україні все популярнішим стає внутрішній туризм. Сьогодні ми все більше відкриваємо свою країну, свій регіон. В Хмельницькій гуманітарно-педагогічній академії готують фахівців з туризму. I сьогодні 
дуже важливим є вивчення туристичних можливостей кожного регіону.

Мета та завдання/Aim and Tasks. Метою дослідження e виявлення можливостей використання регіонального компоненту у підготовці студентів спеціальності 242 «Туризм».

Методи/Methods. Для досягнення мети дослідження використовувалися такі методи дослідження: аналіз, синтез, узагальнення. Для визначення можливостей використання регіонального компоненту у підготовці студентів спеціальності 242 «Туризм» вивчено освітні програми і навчальні плани. В ході вивчення й узагальнення наукової літератури 3 питань дослідження нами використовувався метод порівняння для вирішення поставлених завдань $\mathrm{i}$ досягнення окресленої мети науково-теоретичного пошуку. Використано також статистичний та картографічний методи.

Результати / Results. Визначення цілей освітньої програми орієнтоване на постійний попит у фрахівцях за даною спеціальністю, оскільки в Хмельницькому та області відчуваеться постійний приріст туристів. Ціллю освітньої програми є формування та розвиток у здобувачів вищої освіти загальних та спеціальних компетентностей для успішного здійснення профресійної діяльності у галузі туризму, розвиток практичних навичок.

Унікальність освітньої програми полягає у розвитку туристичної діяльності в умовах становлення територіальних громад, що сприятиме популяризації регіонів України у світовому туристичному просторі. Формування загальних та спеціальних компетентностей здобувачів у галузі туризму, із врахуванням туристичних можливостей Хмельницької області є актуальним. Галузевий контекст враховано під час формулювання цілей та програмних результатів навчання, шляхом аналізу тенденцій розвитку ринку праці, попиту на фрахівців-туризмознавців в регіоні. Постійно проводиться моніторинг вітчизняної сфери туризму 3 метою визначення тенденцій i напрямків розвитку ринку туристичних послуг, з урахуванням регіональної специфріки. Базовою концепцією навчальної та наукової діяльності обрано концепцію сталого туризму задля регіонального розвитку. Включені до освітньої програми дисципліни змістовно охоплюють різні сфери та аспекти туристичної діяльності, що створюе достатні передумови для працевлаштування випускників, практична підготовка протягом навчання у туристичних компаніях.

Налагоджено співробітництво з регіональними підприемствами, з якими підписано угоди про співпрацю, зокрема: Хмельницьким обласним центром туризму і краєзнавства учнівської молоді, Хмельницьким міським центром туризму, краєзнавства та екскурсій учнівської молоді, Хмельницьким обласним краєзнавчим музеєм, музеєм історї міста Хмельницького, Хмельницьким обласним літературним музеєм, Хмельницьким обласним літературним музеєм, заповідником «Межибіж», Національним природним парком «Подільські Товтри», туристичною агенцією «НікаТур-Вояж», «Alice Tour», «Байдак Тур», «Навколо світу - XXI», «Нарpy travel», «Супутник Поділля».

Розроблено освітні компоненти, які надають здобувачам можливість самостійного вибору додаткових професійних якостей. Так, аналіз Програми сощіально-економічного та культурного розвитку Хмельницької області на 2019 та 2020 рр. - свідчить про позитивні тенденції у розвитку туристичної сдери регіону. Приймаємо участь у розробленні регіональних програм розвитку туристичних дестинацій, беремо участь у реалізації науково-дослідної теми: «Розвиток регіонального туристичного комплексу в умовах децентралізації».

Функціонуе науковий гурток «Туризмознавець», мета якого поглиблення загальних та професійних компетентностей в галузі туризму, що направлені на здобуття студентом знань, вмінь i навичок успішної роботи в сфрері обслуговування туристичного комплексу країни і дозволяють йому бути екологічно відповідальним, соціально мобільним та затребуваним на ринку праці. Здобувачі освіти задіяні до практичної розробки та реалізації туристичного продукту в рамках проекту «Туристичні Магніти», яку активно розробляе Хмельницька область. Практична підготовка здобувачів здійснюеться у формі проходження навчальної та виробничої практик в туристичних організаціях різного спрямування.

Одним з важливих напрямів розвитку туризму в Хмельницькій області є екскурсійний туризм, 3 метою відображення цієї тенденції впроваджено дисципліну «Організація екскурсійної та анімаційної діяльності». Освітня програма підготовки бакалаврів за спеціальністю 242 «Туризм» базуеться на моніторингу вітчизняної сфери туризму та ринку освітніх послуг. Регіональний компонент представлений в підтемах дисциплін «Рекреащійні комплекси світу», «Географія туризму» та «Географія України», що передбачають поєднання теоретичного матеріалу, який надається на лекціях, 3 формуванням умінь та навичок, що набуваються при підготовці та проведенні семінарських занять і презентації отриманих результатів, під час практик та підготовки кваліфікаційної роботи бакалавра. Дисципліни мають лекційну частину, де отримуються знання, та семінарську частину, спрямовану на закріплення знань та формування вмінь та навичок аналітико-дослідницької роботи. Завдання переважно індивідуальні, варіативні, що дозволяе врахувати наукові інтереси здобувача. 
Розвиток регіонального туристичного комплексу Хмельницької області відбувається під впливом взаемодії таких чинників: економічних, соціальних, природних, екологічних. Значною мірою чинна система розселення визначае можливості доступності до тих чи інших туристичних принад (дестинацій). Власне локалізують розміщення більшості видів туризму наявні історикокультурні та природні ресурси, що використовують чи можуть використати для реалізації туристичної діяльності. Для організації повноцінного відпочинку туристів важлива також соціальна інфраструктура: наявність об’ектів житлово-комунального господарства, підприемств культурно-побутового обслуговування, охорони здоров'я, торгівлі.

У регіоні лише у 27 населених пунктах діяли заклади колективного розміщення населення і в 10 - підприемства з надання туристичних послуг, а також у 27 сільських населених пунктах розташовані агрооселі (2018р.). Така виразна диспропорція свідчить, з одного боку, про виразну поляризацію соціально-економічних процесів у Хмельницький області. Майже половину вартості реалізованих послуг у сфері туризму припадало на найбільший туристичний центр у Хмельницькій області - м. Кам'янець-Подільський (Долинська О., 2020). Це дозволяе виділити його як полюс туристичної діяльності національного рівня. У деяких територіальних громадах регіону взагалі відсутні підприемства туристичної діяльності. Це зумовлено й природними, i суспільними передумовами та чинниками. Сучасний наявний природно-заповідний й історикокультурний фонди Хмельницької області використовуеться дуже нерівномірно. Більша частина другого 3 них зосереджена в південному районі регіону, водночас найбільші лісові масиви розташовані в північному районі. Це вказуе на виразну невідповідність стану заповідання природи в регіоні з наявним для цього потенціалом. Для виміру насиченості території туристичною функцією ми пропонуемо використати відповідний коефіціент. Розрахунок показав, що існуе виразна поляризація в поширенні, адже помітний спочатку його ступеневий розподіл між двома містами - головними осередками туристичної діяльності в Хмельницькій області - Хмельницьким i Кам'янець-Подільським, водночас решта адміністративно-територіальних одиниць регіону мають більш рівномірний лінійний розподіл його значення. Це дозволяе нам стверджувати про існування на базі цих двох туристичних вузлів та дисперсних кущів виразних полюсів туристичної діяльності в регіоні, що призвело до гіперконцентрації туристичної діяльності в туристичних біфункціональних вузлах і центрах. Місто Кам'янець-Подільський залишається найбільшою туристичною принадою (дестинацією) Хмельницької області. Відзначимо унікальне поєднання різночасової архітектурної спадщини в рамках національного історико-архітектурного заповідника «Кам'янець». Саме Кам'янець-Подільський район $є$ поряд 3 Ізяславською і Летичівською територіальними громадами одним із лідерів за кількістю пам'яток національного значення, розташованих на території Хмельницької області.

Регіональний туристичний комплекс Хмельницької області має у своєму складі 58 точкових елементів територіальної структури та два дисперсні туристичні кущі з вузлами в містах Кам'янець-Подільський i Хмельницький. Перше з цих міст ми визначаємо як туристичну «суперточку» національного значення. На території регіону фрункціонуе 18 моно- i 17 біфункціональних туристичних пунктів та 1 моно- і 10 біфункціональних центрів, а також 1 моно- i 2 біфункціональні кластери (Долинська О., 2020).

Це важливо врахувати при обтрунтуванні пропозицій щодо їхнього соціально-економічного розвитку та територіального планування в умовах реформи децентралізації.

Для виміру насиченості території туристичною функцією ми пропонуемо використали таку формулу:

$$
k=\frac{P}{\sqrt{ } \frac{S}{n}}
$$

де, $k$ - коефіціент насиченості території туристичною функцією, $P$ - кількість туристичних підприемств в адміністративно-територіальних одиницях, $S$ - площа адміністративнотериторіальних одиниць, $n$ - кількість населених пунктів, де наявні туристичні підприемства (Долинська О., 2020).

Існує виразна поляризація в його поширенні, адже спочатку бачимо ступеневий розподіл між двома містами - головними осередками туристичної діяльності в Хмельницькій області Хмельницьким i Кам'янець-Подільським, водночас решта адміністративно-територіальних одиниць регіону мають більш рівномірний лінійний розподіл його значення. Це дозволяе нам стверджувати про існування на базі цих двох туристичних вузлів та дисперсних кущів виразних полюсів туристичної діяльності в регіоні, що призвело до гіперконцентрації туристичної діяльності в туристичних біфункціональних вузлах і центрах, що добре видно на рис. 1. 

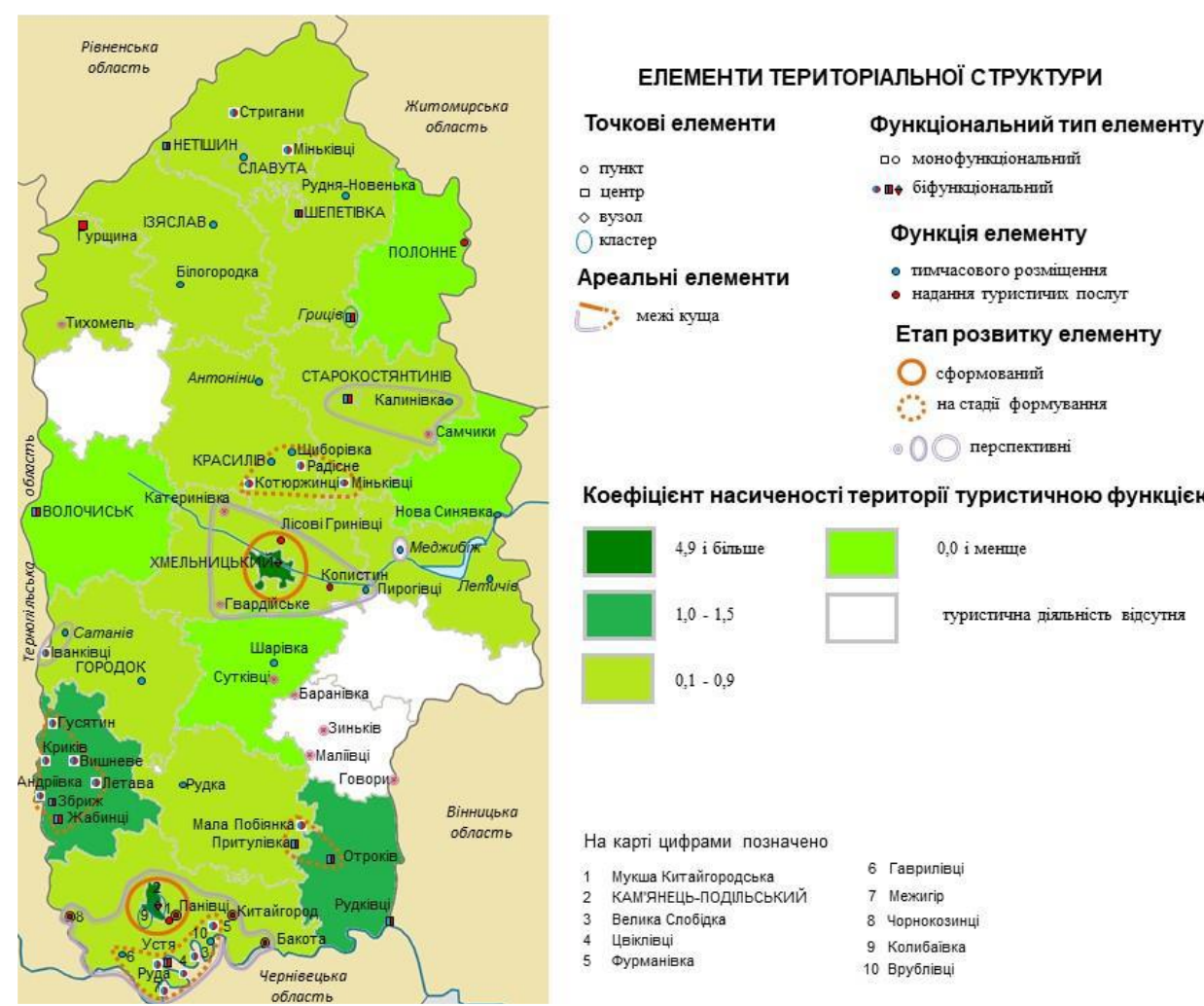

Коефіцієнт насиченості території туристичною функцією, одиниць
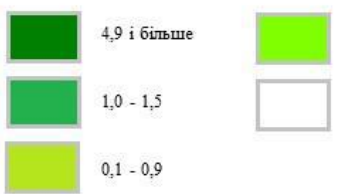

0,0 і менще

Рис. 1 Територіальна структура регіонального туристичного колплексу

Хлельницької області

Прилітка: складено автором самостійно на підставі власних обрахунків за офріційними даними Головного управління статистики в Хмельницькій області та Хмельницької обласної державної адміністрації

Наявність усіх типів точкових елементів територіальної структури в Хмельницькій області свідчить про розвиненість процесів комплексотворення, що обумовило утворення більш складних елементів ареального типу. До таких елементів територіальної структури регіонального туристичного комплексу Хмельницької області належать: сформовані Хмельницький і Кам'янецьПодільський біфункціональні дисперсні кущі та чотири біфункціональні туристичні дисперсні кущі, що формуються. Вирізняеться процес формування біфункціонального туристичного міжрайонного куща на межі Дунаєвецької і Новоушицької територіальної громади й туристичних кущів у Красилівській і Чемеровецькій територіальній громаді. У підприемствах туристичної діяльності Хмельницької області переважали приватні підприемства. Значною мірою це зумовлено тим, що ця форма організації підприемства є єдиною для 55 агроосель регіону. Друге місце займають товариства з обмеженою відповідальністю, що у сфері туризму Хмельницької області представлені винятково в сегменті туристичних компаній. Вони створили найбільшу в регіоні мережу агентів - дочірніх підприемств (Долинська О., 2020). Назріло питання вдосконалення наявної ситуації шляхом формування у рамках кластерних утворень нових організаційнофрункціональних фрорм організації господарської діяльності (наприклад, у фрормі приватних акціонерних товариств).

Кластери виступають у туризмі на локальному рівні в якості інтеграторів соціальноекономічного розвитку, що призводять до утворення нових фрорм територіальної організації (Мезенцев К., 2005). На території Хмельницької області було засновано перший в Україні сільський туристичний кластер агроосель «Оберіг» у смт Гриців (Шепетівський район). Також діє туристичний кластер «Кам'янецький дивокрай» (с. Колибаївка, Кам’янець-Подільський район) та кластери в м. Кам'янець-Подільський «Подільська гільдія ремісників» i «Кам'янець». Вони $\epsilon$ основою туристичних кущів, що фрункціонують у регіоні. На основі останніх кластерів сдормувався туристичний мікрорайон. Така незначна кількість дає нам підстави стверджувати, що процес комплексотворення в регіональному туристичному комплексі Хмельницької області $€$ незавершеним і тому доцільно запропонувати пропозиції щодо його оптимізації та подальшого розвитку. Розбудова в Кам'янець-Подільському районі туристичного кластера дозволить залучити до масового туризму більшу частину пам'яток матеріальної культури, а це безумовно сприятиме активізації соціально-економічного розвитку місцевих новостворених об'єднаних територіальних громад. Доцільно створити нові туристичні кластери в селищах Меджибіж і Сатанів, орієнтованих 
на іноземних туристів (особливо на віруючих хасидів у першому з цих селиш), та більш тісну взаемодію в міжрегіональному туристичному кластері «Подільсько-Буковинський туристичний кластер», до якого входять міста - Кам'янець-Подільський, Чернівці, Хотин (Кирилюк Л., 2014, с. 583; Парфіненко А., \& Босенко К., 2018, с. 123-128). Таким чином можна досягти ефекту мультиплікатора в соціально-економічному розвитку не лише окремих сільських населених пунктів, а й загалом адміністративно-територіального району.

До головних галузевих напрямків перспективного розвитку туристичної діяльності Хмельницької області належать, на нашу думку, такі: активізація природничого та екологічного масового туризму в північних адміністративно-територіальних одиницях; включення до готових туристичних маршрутів нових об’єктів (наприклад, пам'яток індустріальної спадщини та об’ектів Всесвітньої спадщини людства ЮНЕСКО); ревалоризація вже наявних туристичних об’ектів (збереження та консервація пам'яток, пов'язаних з діяльністю українських державних утворень часів Української національної революції в 1917-1922 pр. у м. Кам'янець-Подільський); розбудова державно-приватного партнерства для збереження та включення до туристичних атракцій пам'яток матеріальної культури, пов'язаних 3 релігійною діяльністю юдеїв; збереження та популяризація нематеріальної культурної спадщини у формі фестивалів, конкурсів, тематичних заходів; облаштування місць для масового відпочинку та туризму в південних придністровських районах на базі наявних агроосель; оновлення експозицій у музеях з метою популяризації маловідомої широкому загалу культурної, історичної, природної спадщини, їхне включення до наявних i нових туристичних маршрутів; сприяння всебічному розвитку в новостворених об’єднаних територіальних громадах у сільській місцевості регіону нових агроосель, які б мали різний туристичний профіль та включали до переліку послуг заходи, які популяризують місцеві пам'ятки природи, історії, культури.

Обговорення / Discussion. До головних проблем у розвитку туристичного комплексу Хмельницької області належать: нерозвиненість туристичної інфраструктури на основних автомагістралях області; недостатня кількість готелів та їхнього номерного фонду; різка поляризація в розміщенні туристичних підприемств; відсутність (за винятком м. Кам'янецьПодільський) туристичної інфраструктури, оріентованої на прийом іноземних туристів; незадіяність більшості нематеріальних видів туристичних ресурсів.

Природні передумови розвитку туризму дозволяють використовувати наявні відповідні ресурси та умови для створення нових місць туристичної діяльності. У Кам'янець-Подільському районі Хмельницької області, через значне розчленування рельефу вздовж водойм, доцільно розвивати різні активні види спортивного туризму (веслування на байдарках, скелелазіння, спортивна риболовля тощо). Поширеність у карстових породах значних суфозійних процесів спричинила утворення в Кам'янець-Подільському районі печер у гіпсових товщах, які епізодично використовують для спелеотуризму (за винятком печери Атлантида). Проведення відповідних робіт дозволить розвивати цей вид спортивного туризму в Хмельницькій області. Доцільно не лише використовувати наявну туристичну інфраструктуру м. Кам'янець-Подільський, а й створювати нові осередки в сільській місцевості, особливо на території національного природного парку «Подільські Товтри», де їхня розбудова передбачена в програмних документах із розвитку цього парку. Сприятливі кліматичні умови в Хмельницькій області дозволяють організовувати тут кліматичні курорти. Доцільно їх розбудовувати в поєднанні з іншими масовими видами туризму, наприклад, масовим дитячим відпочинком на березі природних водойм і на краю лісових масивів (Малиновська О., \& Долгова К., 2013). Можливим е створення у великих лісових масивах північної частини області на території різного типу об’ектів природно-заповідного фонду туристичних закладів і маршрутів, які можна і слід використовувати в поширених видах туризму (екологічний, пішохідний, спортивний тощо). Розвиток різних видів природничого туризму можливий на території регіонального ландшафтного парку «Мальованка», адже він розташований недалеко від м. Шепетівка - великого залізничного вузла, тому е можливим прибуття сюди туристів із Західної, Центральної та Східної України.

У регіоні відсутні значні озера, але набули поширення ставки, де вирощують рибу. Тому можливо розвивати спортивне рибальство та облаштовувати пляжі для відпочинку і купання. За винятком приток Дністра на півдні, решта річок не мають порожистих ділянок, мають спокійну течію, що створюе природні умови для активного використання в теплу пору року для купання i плавання. Наявність невеликих, добре впорядкованих лісових масивів дозволяе організовувати там різні форми активного туризму. Доцільно відповідну діяльність розвивати в рамках розбудови екологічного туризму в національному природному парку «Мале Полісся» на території Славутського й Ізяславського районів. Це дозволить комбіновано використовувати наявні природні умови i ресурси регіону, який переважно $є$ екологічно чистим. Його вигідне транспортногеографічне напівпериферійне положення в Україні дозволяе приймати на літній відпочинок 
туристів з різних регіонів держави (Grytsevych V., Podvirna K., \& Senkiv M., 2019). Міста Хмельницький і Шепетівка є важливими залізничними вузлами загальнодержавного значення на території регіону. Це сприяе розвитку туризму в прилеглих районах. Важливо там організувати агрооселі для туристів з різних регіонів держави. Тому важливою в розвитку транспортної мережі регіону е наявність автомобільних доріг із твердим покриттям до населених пунктів, у яких планують розвивати чи вже розвивають туристичну діяльність. Особливо великого значення набувае стан дорожнього покриття на автомобільних шляхах місцевого значення.

Важливе значення для розвитку туризму має організація курсування по р. Дністер у межах Хмельницької області (Дністровське водосховище) малих водних пасажирських транспортних суден для туристів у літній період, коли на його берегах відпочивае найбільша кількість рекреантів, та облаштування інфраструктури. Для Хмельницької області характерною е вища за середню людність сільських населених пунктів Кам'янець-Подільському та Хмельницькому районах. Це вказуе на те, що села в цих районах мають стабільну соціально-економічну ситуацію, тут можливе створення агросадиб, започаткування інших форм сільського (зеленого) туризму. Специфріка історичного розвитку регіону зумовила розміщення на його території п'яти місць поховань хасидських праведників, до яких приїжджають поклонитися юдеї зі всього світу, у містах i селищах: Ганнопіль, Меджибіж, Полонне, Славута, Шепетівка. Окреме місце повинно посісти використання нематеріальної спадщини, зокрема, розвиток у малих міських поселеннях Хмельницької області релігійного туризму юдеїв, які відвідують місця упокоення духовних лідерів. Для цього потрібно розвивати інфраструктуру прийому - місця колективного перебування i громадського харчування, відновити прийом міжнародних авіарейсів в обласному центрі та облаштувати автодороги до головних туристичних дестинацій регіону. Потрібно створити на території Хмельницької області один новий дисперсний кущ у Старокостянтинівському районі, два нові кластери - у смт Меджибіж і Сатанів, 13 нових туристичних пунктів. 3 огляду на агропромисловий економічний профіль Хмельницької області доцільно утворити точкові елементи територіальної структури туристичної діяльності саме на базі агроосель.

Висновки / Conclusions. Вказані головні галузеві напрямки перспективного розвитку туристичної діяльності Хмельницької області, на нашу думку, потрібно реалізувати шляхом проведення таких змін у територіальній організації регіонального туристичного комплексу: подальша розбудова Хмельницького і Кам'янець-Подільського туристичних вузлів за рахунок включення до їхнього складу нових пунктів і центрів у прилеглих до них адміністративнотериторіальних районах; визнання пріоритетним розвитку туристичної діяльності в південній (придністровській) частині Кам'янець-Подільського району; активізація зусиль щодо закріплення статусу туристичної «суперточки» за м. Кам'янець-Подільський не лише в межах України, а й всіеї Центрально-Східної Європи; завершення формування наявних у регіоні туристичних дисперсних кущів шляхом відбору населеного пункту-вузла та посилення зв'язків між ним та туристичними пунктами й центрами в зоні його впливу; сприяння утворенню нового ареального територіального утворення у формі дисперсного туристичного куща в Старокостянтинівській територіальній громаді) на базі існуючих пам'яток матеріальної культури; включення до туристичних маршрутів нових туристичних пунктів. Ці знання є важливими у підготовці студентів спеціальності 242 «Туризм».

\section{Список використаних джерел і літератури:}

Долинська, О. О. (2020). Туристичний колплекс Хмельницької області: сучасний стан та перспективи розвитку: дис. ... д-ра філософії: 103 Науки про Землю / Київський національний університет імені Тараса Шевченка. Київ. 245. [in Ukrainian].

Кирилюк, Л. М. (2014). Перспективи створення туристичних кластерів на території Поділля. Геополитика и экогеодиналика регионов, 2 (13), 10, 580-584. [in Ukrainian].

Малиновська, О. Ю., \& Долгова, К. С. (2013). Ринок дитячого туризму: інноваційні форми організації відпочинку. Географбія та туризм, 24, 60-69.[in Ukrainian].

Мезенцев, К. В. (2005). Суспільно-географбічне прогнозування регіонального розвитку. Київ: Видавничополіграфічний центр «Київський університет». [in Ukrainian]

Парфіненко, А. Ю., \& Босенко, К. І. (2018). Кластеризація як напрям рекреаційно-туристичного розвитку Подільського регіону України. Вісник Харківського наиіонального університету імені В. Н. Каразіна. Сер.: Міжнародні відносини. Економіка. Країнознавство. Туризм, 7, 122-129. [in Ukrainian]

Grytsevych, V. S., Podvirna, K. Y., \& Senkiv, M. I. (2019). Motor transport network in the Western region of Ukraine. Вісник Харківського національного університету імені В. Н. Каразіна. Сер.: Геологіл. Геограббія. Екологія, 50, 91-98. [in English]

\section{References:}

Dolynska, O. O. (2020). Turystychnyi kompleks Khmelnytskoi oblasti: suchasnyi stan ta perspektyvy rozvytku [Tourist Complex of Khmelnytskyi Region: Current State and Prospects of Development]: Doctor's of Philosophy 
Thesis: 103 Nauky pro Zemliu / Kyivskyi Natsionalnyi Universytet imeni Tarasa Shevchenka. Kyiv. 245. [in Ukrainian].

Kyryliuk, L. M. (2014). Perspektyvy stvorennia turystychnykh klasteriv na terytorii Podillia [Prospects for the Creation of Tourist Clusters in Podillia]. Geopolitika $i$ e'kogeodinamika regionov - Geopolitics and ecogeodynamics of regions, 2 (13), 10, 580-584. [in Ukrainian].

Malynovska, O. Yu., \& Dolhova, K. S. (2013). Rynok dytiachoho turyzmu: innovatsiini formy orhanizatsii vidpochynku [Children's Tourism Market: Innovative Forms of Recreation]. Heohrafiia ta turyzm - Geography ahnd Tourism, 24, 60-69.[in Ukrainian].

Mezentsev, K. V. (2005). Suspilno-heohrafichne prohnozuvannia rehionalnoho rozvytku [Socio-Geographical Forecasting of Regional Development]. Kyiv: Vydavnycho-polihrafichnyi tsentr «Kyivskyi universytet». [in Ukrainian]

Parfinenko, A. Yu., \& Bosenko, K. I. (2018). Klasteryzatsiia yak napriam rekreatsiino-turystychnoho rozvytku Podilskoho rehionu Ukrainy [Clustering as a Direction of Recreational and Tourist Development of the Podolsk Region of Ukraine]. Visnyk Kharkivskoho natsionalnoho universytetu imeni V. N. Karazina. Ser.: Mizhnarodni vidnosyny. Ekonomika. Krainoznavstvo. Turyzm - Bulletin of V. N. Karazin Kharkiv National University. Ser.: International Relations. Economy. Local Lore. Tourism, 7, 122-129. [in Ukrainian]

Grytsevych, V. S., Podvirna, K. Y., \& Senkiv, M. I. (2019). Motor transport network in the Western region of Ukraine. Visnyk Kharkivskoho natsionalnoho universytetu imeni V. N. Karazina. Ser.: Herolohiia. Heohrafiia. Ekolohiia - Bulletin of V. N. Karazin Kharkiv National University. Ser.: Geology. Geography. Ecology, 50, 91-98. [in English]

Дата надходження статті: «06» травня 2021 р.

Стаття прийнята до друку: «04» червня 2021 р.

Долинська Олеся - доцент кафедри туризму, теорії і методики фрізичної культури та валеології Хмельницької гуманітарно-педагогічної академії, доктор фрілософiї

Dolynska Olesia - Associate Professor of the Department of Tourism, Theory and Methods of Physical Culture and Valeology of Khmelnytskyi Humanitarian-Pedagogical Academy, Doctor of Philosophy

Цитуйте иљю статтю як:

Долинська, О. (2021). Особливості використання регіонального компоненту у підготовці студентів спеціальності 242 «Туризм». Педагогічний дискурс, 30, 56-62. doi: 10.31475/ped.dys.2021.30.07.
Cite this article as:

Dolynska, O. (2021). Features of Using the Regional Component in Training Students of Program Subject Area 242 «Tourism». Pedagogical Discourse, 30, 56-62. doi: 10.31475/ped.dys.2021.30.07. 